\title{
Penatalaksanaan Hipersensitivitas Dentin
}

\author{
Novia D. P. Rasni, Johanna A. Khoman
}

Program Studi Pendidikan Dokter Gigi Fakultas KedokteranUniversitas Sam Ratulangi, Manado, Indonesia

Email: vivirasni27@gmail.com

\begin{abstract}
Dentin hypersensitivity is one of the most common dental problems. It can be found in both sexes, especially in the elderly. The discomfort or pain experienced in cases of dentin hypersensitivity occurs due to the unprotected surface by enamel in the crown or by cementum in the tooth root area. The characteristic of dentin hypersensitivity is that the pain suffered is acute, sharp but short in the unprotected dentin. This review was aimed to discuss about the etiology, stimulatory transmission mechanisms, and management of dentine hypersensitivity.

Keywords: dentin hypersensitivity; pain
\end{abstract}

\begin{abstract}
Abstrak: Hipersensitivitas dentin merupakan salah satu masalah gigi yang paling sering dijumpai, dapat ditemui pada laki-laki maupun perempuan utamanya pada orang yang sudah lanjut usia. Ketidaknyamanan atau rasa ngilu yang dialami pada kasus hipersensitif dentin terjadi karena adanya permukaan yang tidak terlindungi oleh email di mahkota atau sementum di daerah akar gigi. Ciri khas hipersensitivitas dentin yaitu rasa sakit yang diderita bersifat akut, tajam tapi singkat pada dentin yang tidak terlindungi. Penulisan ini bertujuan untuk membahas mengenai etiologi, mekanisme penjalaran rangsang dan tata kelola kasus hipersensitivitas dentin.
\end{abstract}

Kata kunci: hipersensitivitas dentin; rasa ngilu

\section{Pendahuluan}

Hipersensitivitas dentin merupakan masalah yang dapat ditemukan sehari-hari baik pada laki-laki maupun perempuan terutama yang beranjak lanjut usia. Keluhan ngilu, nyeri, atau sakit dirasakan tidak hanya karena gigi berkontak dengan minuman atau makanan yang dingin maupun panas, menyikat gigi, makan makanan yang manis tetapi juga oleh penyebab yang terasa tidak mungkin misalnya udara/angin pada saat membuka mulut. Kadang-kadang sulit untuk menggambarkan rasa ngilu atau nyeri yang dialami, tetapi umumnya dilaporkan sebagai rasa ngilu/nyeri tajam dengan durasi singkat yang terjadi sebagai respons terhadap stimuli, tersering ialah stimuli termal, evaporatif, taktil, osmotik, atau kimiawi. ${ }^{1-3}$

Laporan penelitian mengenai prevalen- si hipersensitivitas dentin masih jarang dan kontradiktif dengan rentang persentase yang lebar. Prevalensi hipersentivitas dentin yang dilaporkan sebesar 3,8-74,0\%, tergantung dari populasi serta bentuk dan desain studi. ${ }^{3}$ Cunha-Cruz et $\mathrm{al}^{3}$ melakukan suatu penelitian survei dengan desain potong lintang pada dokter gigi praktek sejak September 2010 sampai dengan Mei 2011 dalam the Northwest Practice-based Research Collaborative in Evidence-based DENTistry (PRECEDENT) untuk mendapatkan prevalensi hipersensitivitas dentin. Penelitian tersebut dilakukan terhadap 787 pasien dewasa dari 37 dokter gigi praktek yang tergabung dalam PRECEDENT. Hasil penelitian tersebut mendapatkan prevalensi hipersensitivitas dentin sebesar 12,3\%, yang lebih sering pada usia 18-44 tahun, jenis kelamin perempuan, adanya resesi 
gingival, dan riwayat penggunaan pemutih gigi sendiri. Splieth et $\mathrm{al}^{4}$ juga melakukan suatu systematic review dan melaporkan prevalensi hipersensitivitas dentin dengan rentang yang lebar yaitu sebesar 3-98\%. Hal ini dapat disebabkan karena perbedaan kriteria sampel penelitian dan pendekatan diagnostik atau waktu penelitian. Jenis kelamin perempuan sedikit lebih sering terkena dengan rentang usia 30-40 tahun. Penelitian systematic review dan meta analisis oleh Zeola et al $^{5}$ mengenai prevalensi hipersensitivitas dentin pada berbagai populasi dilakukan dengan menggunakan beberapa database elektronik. Hasil penelitiannya mendapatkan prevalensi hipersensitivitas dentin yang paling rendah ialah $1,3 \%$ dan yang paling tinggi ialah $92,1 \%$.

Hipersensitivitas dentin masih merupakan masalah klinis yang persisten dan tantangan tersendiri bagi para klinisi yang sangat memengaruhi kualitas hidup pasien. Selain itu data epidemiologi mengenai hipersensitivitas dentin masih kurang dan kontradiktif. ${ }^{4,5}$ Berdasarkan latar belakang yang telah diuraikan maka penulis tertarik untuk membahas mengenai masalah hipersensitivitas dentin agar mendapatkan pemahaman yang baik mengenai patogenesis dan hal-hal terkait yang dapat membantu dalam menentukan tindak lanjut pada penanganan pasien dengan hi[ersensitibitas dentin.

\section{Etiologi}

Penyebab nyeri/ngilu gigi dapat diklasifikasikan sebagai nyeri/ngilu dengan kavitas karena adanya kavitas atau karies, misalnya karena abrasi, atrisi, erosi atau abfraksi; dan nyeri/ngilu tanpa kavitas, umumnya karena terjadi resesi gingiva yang menyebabkan permukaan akar terbuka, dan ngilu setelah perawatan bleaching, scaling dan root planing, restorasi yang cacat, sindroma gigi retak, penggunaan bur tanpa air pendingin. dan lain-lain. ${ }^{6,7}$

Karies gigi merupakan penyakit infeksi mulut multifaktorial yang dapat ditransmisi karena adanya interaksi antara flora mulut/bakteri kariogenik (biofilm) dengan diet karbohidrat yang terfermentasi di permukaan gigi dalam jangka waktu yang lama. Aktivitas tersebut menyebabkan demineralisasi lokal dan mengakibatkan adanya struktur gigi yang hilang. Demineralisasi fase inorganik dan denaturasi serta degradasi fase organik menyebabkan terbentuknya kavitas di dentin. ${ }^{6}$ Pulpa yang mengalami iritasi menimbulkan rasa tidak nyaman/ngilu tetapi cepat pulih setelah iritannya dihilangkan dan didiagnosis sebagai pulpitis reversibel. Penyebabnya antara lain karies, dentin yang terbuka, serta perawatan dental dan restorasi yang cacat. $^{7}$

Abrasi adalah keausan di permukaan gigi, yang umumnya di bagian servikal permukaan bukal/fasial disebabkan adanya gesekan benda-benda asing, misalnya sikat gigi yang kasar, pasta gigi yang abrasif, dan lain-lain. ${ }^{6,8}$ Abfraksi secara klinis mirip abrasi, merupakan kerusakan di bagian servikal gigi yang disebabkan oleh kekuatan oklusi eksentrik yang menyebabkan terjadi cekungan yang tajam, biasanya karena pasien mengalami bruksisma atau maloklusi. ${ }^{6,9}$ Atrisi adalah keausan di permukaan insisal atau oklusal gigi karena faktor mekanis sebagai akibat terjadi pergerakan fungsional atau parafungsional dari mandibula. ${ }^{6,8}$ Erosi adalah hilangnya struktur permukaan gigi karena faktor kimia, misalnya konsumsi makanan/ minuman asam yang menyebabkan penurunan $\mathrm{pH}$ saliva dalam rongga mulut sehingga terjadi demineralisasi email yang menyebabkan terpaparnya dentin. ${ }^{6,10}$ Erosi dapat pula dikatakan sebagai demineralisasi sebagian email atau dentin akibat asam yang berasal dari ekstrinsik maupun intrinsik, dan secara klinis dapat berkombinasi dengan abrasi atau abfraksi. ${ }^{10}$

Abrasi, abfraksi, atrisi maupun erosi tidak melibatkan bakteri namun pada kasus yang cukup parah maka respon pulpa memberi reaksi serupa pulpitis reversibel. Hipersensitivitas dentin dikatakan sebagai nyeri/ngilu pada gigi yang menyebabkan respon pulpa vital berlebihan terhadap berbagai stimulasi. Hal ini terjadi karena dentin terbuka terhadap lingkungan mulut yang menyebabkan rasa tidak nyaman. ${ }^{11}$ Pada kasus demikian tidak terdapat kavitas 
sebagaimana halnya lesi dengan kavitas karies atau non karies.

Hipersensitivitas dentin terutama ditemukan pada kasus resesi gingiva yang menyebabkan terpaparnya permukaan akar terhadap berbagai rangsangan panas, dingin, asam, manis, maupun udara. ${ }^{11}$ Permukaan akar aspek fasial dari gigi kaninus, premolar dan molar merupakan area yang paling sering kehilangan perlekatan periodontal dan dapat meningkat setelah menjalani perawatan scaling serta root planing. Hipersensitivitas dentin terjadi akibat berkurangnya perlindungan sementum, smear layer dan pergerakan hidrodinamik cairan dalam tubulus dentinalis. Gejala inflamasi pulpa dalam hal ini tidak spesifik tetapi pada kasus dentin sudah terbuka maka keluhannya dapat dianggap sebagai inflamasi reversibel yang terlokalisasi. Terdapat dua hal yang perlu mendapat perhatian untuk mendiagnosis hipersensitivitas dentin, yaitu adanya dentin yang terpapar dan tubulus dentinalis yang terbuka. Perlu diketahui bahwa tidak selalu dentin yang terpapar akan mengalami hipersensitivitas. ${ }^{2}$

Resesi gingiva adalah kondisi permukaan akar terbuka karena hilang atau tertariknya atau retraksi gingiva ke arah akar yang mengakibatkan permukaan akar tidak terlindung. Resesi gingiva umumnya terjadi di usia 40 tahun ke atas, tetapi bisa juga ditemukan pada usia yang lebih muda. $^{12}$

Bleaching adalah tindakan untuk memutihkan gigi yang mengalami perubahan warna, dapat disebabkan secara ekstrinsik maupun intrinsik dari gigi. Terdapat dua cara untuk perawatan bleaching, yaitu bleaching vital yang dilakukan pada gigi dengan pulpa vital dan bleaching non-vital yang dilakukan pada gigi yang telah dirawat endodontik. Perawatan bleaching vital pada gigi berpotensi meng-iritasi pulpa sehingga menyebabkan hipersensitivitas dentin, namun pulpa tetap vital. ${ }^{2}$

Scaling dan root planing merupakan tindakan untuk menghilangkan kalkulus baik supra dan sub gingival Perawatan ini merupakan tindakan non-bedah untuk mengeluarkan plak dan tartar yang terletak di bawah gingiva. Akibatnya dapat menyebabkan rasa ngilu setelah perawatan karena hilangnya sementum yang melindungi akar gigi. ${ }^{12}$

\section{Mekanisme Penjalaran Rasa Nyeri}

Berbagai teori dikembangkan untuk memahami bagaimana perjalanan rangsangan dikirim ke otak sehingga diterima sebagai rasa ngilu atau nyeri, misalnya teori transdusi, teori modulasi, teori vibrasi, kontrol "pintu gerbang," serta teori hidrodinamik. ${ }^{13}$

Transmisi rangsang dari dentin yang terbuka ke ujung akhir saraf yang berlokasi di dalam pulpa gigi melalui prosesus odontoblas merupakan dasar teori mekanisme hidrodinamik. Dikatakan bahwa ketika terjadi kehilangan email atau sementum maka tubulus dentinalis terbuka ke rongga mulut. Adanya rangsang tertentu menyebabkan pergerakan cairan di dalam tubulus, secara tidak langsung akan merangsang ujung akhir saraf di dalam pulpa yang akan diteruskan ke otak dan dipersepsi sebagai rasa ngilu, nyeri, atau sakit. ${ }^{13}$

\section{Tatalaksana Hipersensitivitas Dentin}

Berdasarkan teori hidrodinamik, maka dasar pemikiran dari perawatan dentin hipersensitivitas ialah menghalangi menjalarnya rangsang dengan cara menutup tubulus dentinalis yang terbuka. Hipersensitivitas dentin karena adanya kavitas, baik yang disebabkan karies atau non karies memerlukan restorasi yang sesuai yaitu melapisi dengan semen ionomer kaca, bahan adesif, atau komposit. Pada kasus tanpa kavitas, berbagai bahan dan teknik dikembangkan untuk mengatasi keluhan hipersensitivitas dentin, misalnya pasta gigi khusus, iradiasi laser dengan karbon dioksida, dentin adesif, agen antibakteri, aldehida, suspensi resin, membilas dengan fluorid, varnish fluoride, kalsium fosfat, potasium nitrat, dan oksalat. Agen desensitisasi dibedakan atas klasifikasi cara pemberian, yaitu at home atau in-office, dan klasifikasi berdasar mekanisme aksi. ${ }^{14,15}$ 
Klasifikasi berdasarkan mekanisme aksi dibedakan atas mekanisme kerjanya, yaitu mengganggu respon neural terhadap stimulus sakit (desensitisasi saraf dengan menggunakan potasium nitrat) dan memblok aliran cairan tubuler sehingga menutup tubulus dentinalis. Sebagai contoh ialah presipitasi protein dengan glutaraldehida, silver nitrate, zinc chloride, dan strontium chloride hexahydrate; menghambat tubulus dentinalis dengan sodium fluoride, stannous fluoride, strontium chloride, potassium oxalate, calcium phosphate, calcium carbonate, dan bioactive glasses ( $\mathrm{SiO} 2-\mathrm{P} 2 \mathrm{O} 5-$ $\mathrm{CaO}-\mathrm{Na} 2 \mathrm{O}$ ); serta pelapis (sealer) dentin adesif dengan fluoride varnishes, oxalic acid and resin, glass ionomer cement, komposit, dan dentin bonding agent; laser dengan neodymium: yttrium aluminum garnet (Nd-YAG) laser, GaAlAs (galiumaluminium-arsenide laser), dan ErbiumYAG laser; medikasi homeopathic dengan propolis. ${ }^{14,15}$ Terdapat berbagai teknik aplikasi agen desensitisasi dentin dalam bermacam-macam bentuk, misalnya krim topikal, varnish, pasta gigi, bubuk polis, single dose applicator, campuran bubuk/cairan, dan modifikasi resin.

Strategi perawatan dentin hipersensitivitas ialah diagnosis dan rencana perawatan yang tepat serta dental health education (DHE) mengenai faktor etiologi. Pada kasus sensitivitas ringan sampai sedang, diberikan DHE mengenai metode penyikatan gigi yang benar dan pemilihan pasta gigi yang sesuai dan dapat dilakukan di rumah (therapy at home). Bila masih tetap merasa ngilu dapat dilanjutkan dengan perawatan di ruang dokter (inoffice therapy) menggunakan sistem iontophoresis dengan alat khusus, yaitu desensitron. Apabila kedua cara tersebut belum efektif, maka dipertimbangkan perawatan endodontik sebagai langkah terakhir. ${ }^{14,15}$

Sebagai indikasi penatalaksanaan hipersensitivitas dentin ialah gigi dengan resesi gingiva 1 dan 2 miller; gigi tanpa abrasi, abfraksi, atau atrisi; gigi tanpa karies; dan gigi tanpa kerusakan tulang. Kontraindikasi penatalaksanaan hipersensitivitas dentin ialah gigi dengan resesi miller kelas 3 dan 4; gigi dengan adanya karies, abrasi, abfraksi, atau atrisi; dan gigi dengan adanya kerusakan tulang. ${ }^{12}$

\section{Resesi Gingiva}

Salah satu penyebab utama terjadinya hipersensitivitas dentin ialah resesi gingiva, yaitu terbukanya permukaan akar gigi akibat migrasi gingival margin dan junctionalepithelium ke apikal. Secara klinis ditandai dengan gingival margin berada apikal dari cemento-enamel junction (CEJ). Kondisi ini dapat terjadi pada satu maupun sekelompok gigi, baik pada rahang atas maupun rahang bawah. ${ }^{16}$

Resesi gingiva juga dapat menyebabkan hipersensitivitas dentin akibat terbukanya permukaan akar yang semula tertutup oleh gingiva. Permukaan akar yang terbuka juga memudahkan terjadinya erosi maupun abrasi pada sementum maupun dentin akibat lingkungan rongga mulut maupun akibat aktivitas menyikat gigi. Kondisi ini cenderung menimbulkan rasa nyeri/ngilu jika terkena rangsangan terutama akibat perubahan suhu. Selain itu, permukaan akar yang terbuka menyebabkan gigi rentan terhadap karies servikal. ${ }^{16}$

\section{Faktor Etiologi Resesi Gingiva}

Etiologi resesi gingiva dapat disebabkan oleh beberapa faktor, antara lain: anatomi, fisiologik, maupun patologik. Faktor anatomi yang dapat menyebabkan resesi gingiva ialah fenestration dan dehiscence yang terjadi pada tulang alveolar, posisi gigi di luar lengkung yang normal, serta morfologi akar yang prominen. Semua kondisi tersebut menyebabkan tulang alveolar maupun gingiva yang melapisinya menjadi lebih tipis, sehingga memudahkan terjadinya resesi gingiva. Selain itu, perlekatan frenum dan frenulum yang terlalu koronal, perlekatam gingiva yang sempit, serta faktor keturunan, misalnya epitel gingiva yang tipis dan mudah rusak, cenderung mengakibatkan resesi gingiva. ${ }^{12,16}$

Resesi gingiva secara fisiologik dapat terjadi akibat pergerakan gigi secara ortodontik, baik ke arah lingual maupun 
labial, yang cenderung mengakibatkan terjadinya dehiscence. Bertambahnya usia juga menjadi salah satu penyebab timbulnya resesi gingiva secara fisiologik. ${ }^{16}$

Resesi gingiva secara patologik antara lain dapat terjadi karena peradangan gingiva akibat oral hygiene buruk sehingga terjadi akumulasi plak dan kalkulus, trauma oklusi, trauma sikat gigi, merokok, mengonsumsi alkohol, tepi restorasi yang tidak baik, faktor hormonal, serta akibat prosedur operasi periodontal. ${ }^{12,16}$

Faktor etiologi resesi gingiva yang berhubungan dengan penyakit periodontal cenderung bersifat ireversibel. Sebaliknya, resesi gingiva yang diakibatkan oleh trauma oklusi maupun trauma akibat kesalahan menyikat gigi bersifat reversibel, artinya gingival margin dapat dikembalikan ke posisi normalnya dengan prosedur rekonstruksi periodontal disertai eliminasi penyebabnya. ${ }^{16}$

\section{Klasifikasi Resesi Gingiva}

Menurut Miller, resesi gingiva dibagi atas empat kelas (Gambar 1).

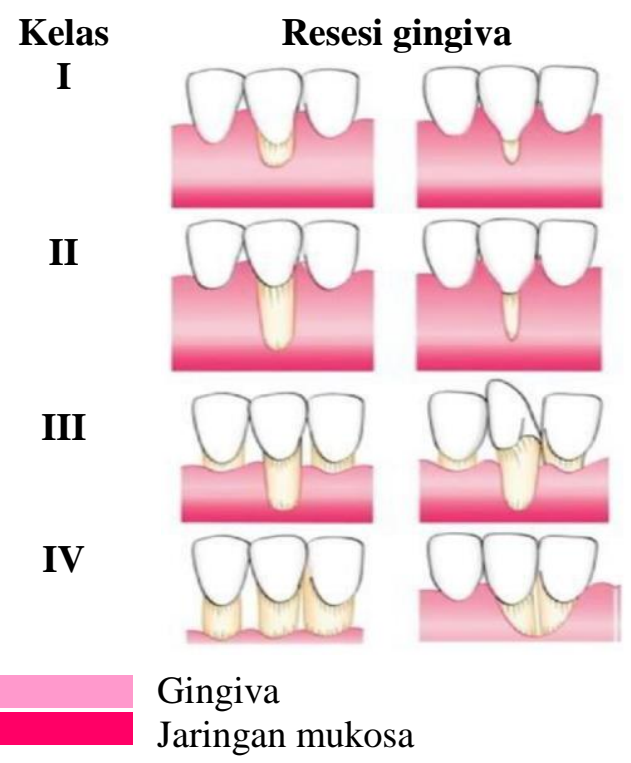

Gambar 1. Resesi gingiva menurut Miller. Sumber: Chrysanthakopoulos NA, 2010. ${ }^{12}$

Pada resesi gingiva kelas I, resesi meliputi jaringan marginal yang tidak meluas ke mucogingival junction dan tidak terdapat kehilangan tulang atau jaringan lunak di daerah interdental. Resesi gingiva kelas II merupakan resesi jaringan marginal meluas ke atau melampaui mucogingival junction, namun tidak terdapat kehilangan tulang atau jaringan lunak di daerah interdental. Resesi gingiva kelas III merupakan resesi jaringan marginal yang meluas ke atau melampaui mucogingival junction disertai kehilangan tulang atau jaringan lunak di daerah interdental dengan atau tanpa malposisi gigi. Resesi gingiva kelas IV merupakan resesi jaringan marginal yang meluas ke atau melampaui тисоgingival junction, disertai hilangnya tulang atau jaringan lunak di daerah interdental dengan atau tanpa malposisi gigi yang sangat parah. ${ }^{12}$

\section{Simpulan}

Hipersensitivitas dentin merupakan keluhan ngilu/nyeri tanpa kavitas, melainkan karena terbukanya tubulus dentinalis.

Hipersensitivitas dentin umumnya disebabkan akibat adanya resesi gingiva di daerah akar gigi, permukaan akar yang terbuka sebagai dampak perawatan scaling dan root planing atau setelah perawatan bleaching. Tindakan yang dilakukan untuk mengatasi keluhan pada kasus ringan dapat dilakukan sendiri di rumah menggunakan pasta gigi khusus untuk gigi sensitif sedangkan untuk kasus berat dilaksanakan oleh dokter gigi di klinik gigi.

\section{Konflik Kepentingan}

Penulis menyatakan tidak terdapat konflik kepentingan dalam penelitian ini.

\section{DAFTAR PUSTAKA}

1. Barlow APS, Mason SC. Overview of the clinical evidence for the use of novamin in providing relief from the pain of dentin hypersensitive. J Clin Dent 2011;22 (Spec Iss):90-5.

2. Fouad AF, Levin L. Pulpal reaction to caries and dental procedures. In: Hargreaves KM, Cohen S, editors. Cohen's Pathways of the Pulp (10th ed). Missouri: Mosby Elsevier, 2011; p. 504-10.

3. Cunha-Cruz J, Wataha JC, Heaton LJ, Rothen M, Sobieraj M, Scott J, et al. The 
prevalence of dentin hypersensitivity in general dental practices in the northwest United States. J Am Dent Assoc. 2013;144(3):288-96.

4. Splieth $\mathrm{CH}$, Tachou A. Epidemiology of dentin hypersensitivity. Clin Oral Investig. 2013;17(Suppl1):3-8. Doi: 10.1007/s00 784-012-0889-8

5. Zeola LF, Soares PV, Cunha-Cruz J. Prevalence of dentin hypersensitivity: Systematic review and meta-analysis. J Dentistry. 2019;81(Feb):106.

6. Ritter AV, Eidson RS, Donovan TE. Dental caries: etiology, clinical characterristics, risk assessment and management. In: Heymann HO, Swift Jr EI, Ritter AV, editors. Sturdevant's Art and Science of Operative Dentistry (6th ed). St Louis: Elsevier, 2013; p. 41.

7. Berman LH, Hartwell GR. Diagnosis. In: Hargreaves KM, Cohen S, editors. Cohen's Pathways of the Pulp (10th ed). Missouri: Mosby Elsevier, 2011; p. 30 .

8. Eidson RS, Shugars DA. Patient assessment, examination and diagnosis, and treatment planning. In: Heymann $\mathrm{HO}$, Swift Jr EI, Ritter AV, editors. Sturdevant's Art and Science of Operative Dentistry (6th ed). St Louis: Elsevier, 2013; p. 99-100.

9. Sarode GS, Sarode SC. Abfraction: a review. J Oral Maxillofac Pathol. 2013; 17(2):222-7.
10. Huysmans MC, Chew HP, Ellwood RP. Clinical studies of dental erosion and erosive wear. Caries Res. 2011;45 (Suppl1):60-8. Doi: 10.1159/00032 5947.

11. Camilotti V, Zilly J, Monte Ribeiro Busato P, Nassar CA, Nassar PO. Desensitizing treatment for dentin hypersensitiveity: a randomized, split-mouth clinical trial. Braz Oral Res 2012;26(3):263-8.

12. Chrysanthakopoulos NA. Occurrence, extension and severity of the gingival recession in a Greek adult population sample. J Periodontol Implant Dent. 2010;2(1):37-42.

13. Perdigão J, Swift EJ, Walter R. Fundamental concept of enamel and dentin adhesion. In: Heymann HO, Swift Jr EI, Ritter AV, editors. Sturdevant's art and science of operative dentistry (6th ed). St Louis: Elsevier, 2013; p.133-4

14. Miglani S, Aggarwal V, Ahuja B. Dentin hypersensitivity: recent trends in management. J Conserv Dent. 2010; 13(4): 218-24.

15. Layer TM. Development of a fluoridated, daily-use toothpaste containing novamin technology for the treatment of dentin hypersensitivity. J Clin Dent. 2011;22 (Spec Iss):59-61.

16. Krismariono A. Prinsip dan dasar perawatan resesi gingiva. Jurnal Dentika Dental. 2014;18(1):96-100. 